\title{
Extracellular electron transfer from cathode to microbes: application for biofuel production
}

\author{
Okkyoung Choi and Byoung-In Sang
}

\begin{abstract}
Extracellular electron transfer in microorganisms has been applied for bioelectrochemical synthesis utilizing microbes to catalyze anodic and/or cathodic biochemical reactions. Anodic reactions (electron transfer from microbe to anode) are used for current production and cathodic reactions (electron transfer from cathode to microbe) have recently been applied for current consumption for valuable biochemical production. The extensively studied exoelectrogenic bacteria Shewanella and Geobacter showed that both directions for electron transfer would be possible. It was proposed that gram-positive bacteria, in the absence of cytochrome $C$, would accept electrons using a cascade of membrane-bound complexes such as membrane-bound Fe-S proteins, oxidoreductase, and periplasmic enzymes. Modification of the cathode with the addition of positive charged species such as chitosan or with an increase of the interfacial area using a porous three-dimensional scaffold electrode led to increased current consumption. The extracellular electron transfer from the cathode to the microbe could catalyze various bioelectrochemical reductions. Electrofermentation used electrons from the cathode as reducing power to produce more reduced compounds such as alcohols than acids, shifting the metabolic pathway. Electrofuel could be generated through artificial photosynthesis using electrical energy instead of solar energy in the process of carbon fixation.
\end{abstract}

Keywords: Bioelectrochemical synthesis, Extracellular electron transfer, Cathodic electron, Electrofuel

\section{Background}

An eventual replacement of fossil energy source with sustainable energy system is unavoidable. Biofuels have emerged as one of the sustainable fuels sources and it is considered as alternatives to petroleum. Biomass captured the energy from sunlight and stored it as highenergy chemical bonds, which is used for biofuels. More recently, electrofuels have been studied for liquid fuels as a means for intermittent electricity storage [1] using the energy of low-potential electrons such as hydrogen gas, reduced metal, or electricity [2]. It usually uses the interaction between microbes and electrode, through extracellular electron transfer.

Bioelectrochemical synthesis (BES) uses extracellular electron transfer of microorganisms catalyzing anodic

*Correspondence: biosang@hanyang.ac.kr

Department of Chemical Engineering, Hanyang University, 222

Wangshimni-ro, Seongdong-gu, Seoul 04763, South Korea and/or cathodic reactions. BES has two categories according to the direction of electron flow, microbial fuel cells (MFC, electricity production), and microbial electrosynthesis (MES, electricity consumption). A microbial fuel cell uses extracellular electron transfer to an electrode originating from organic compounds consumed by microorganisms. Microbial electrosynthesis uses electron transfer from an electrode to microorganisms producing reduced biochemical compounds. An electrode is thus used as an electron acceptor (MFC) or an electron donor (MES).

Extracellular electron transfer has been gaining wide interest in relation to microbial electrochemical synthesis $[1,3]$, interspecies electron transfer $[4,5]$, and microbial immobilization of heavy metals for bioremediation $[6$, 7] (Table 1). In particular, biofuels or biochemicals are reduced compounds and the reducing power is needed in microbial fermentation processes [8,9]. An external supply of electrons using electricity enhances the reducing 


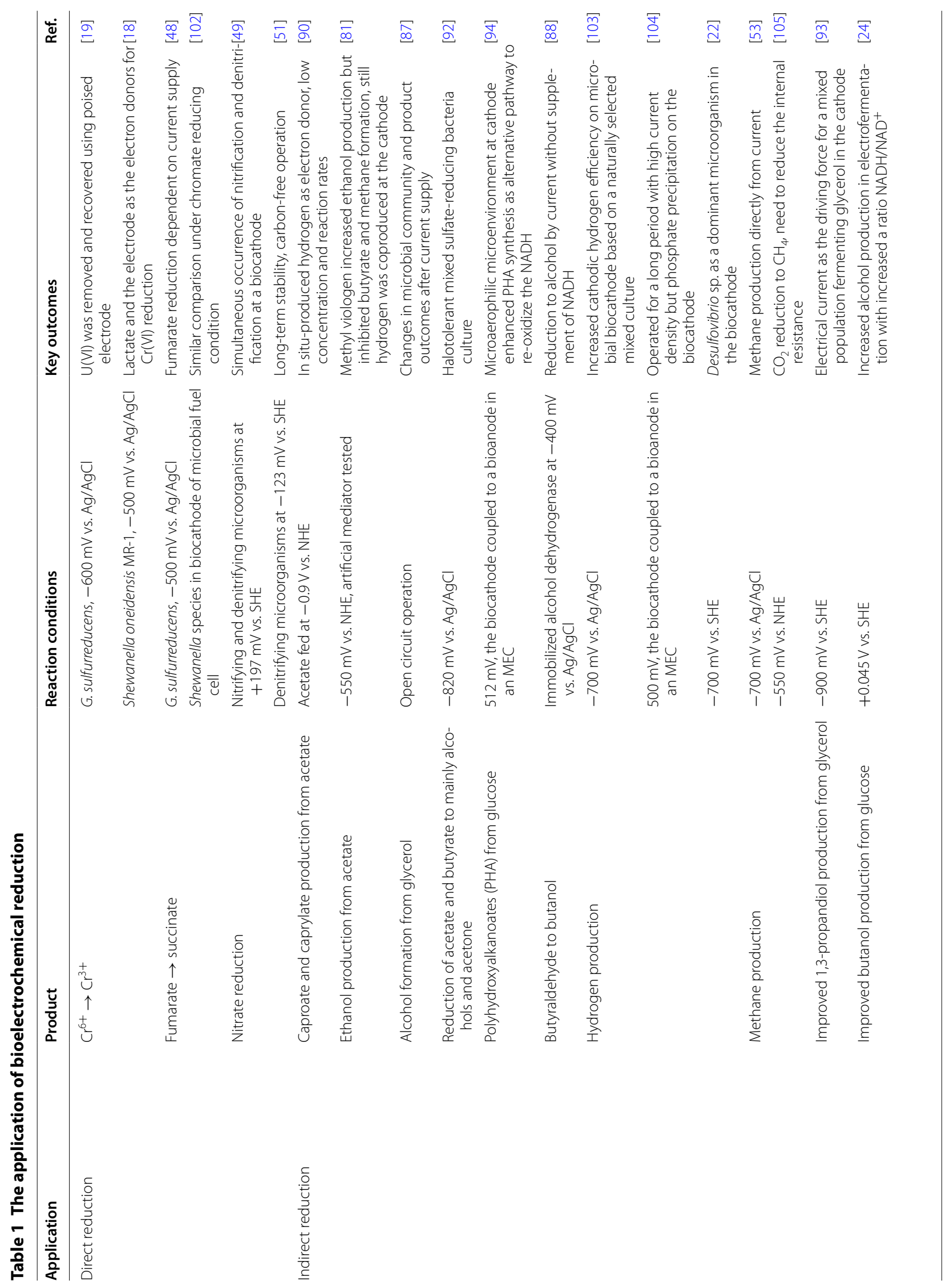




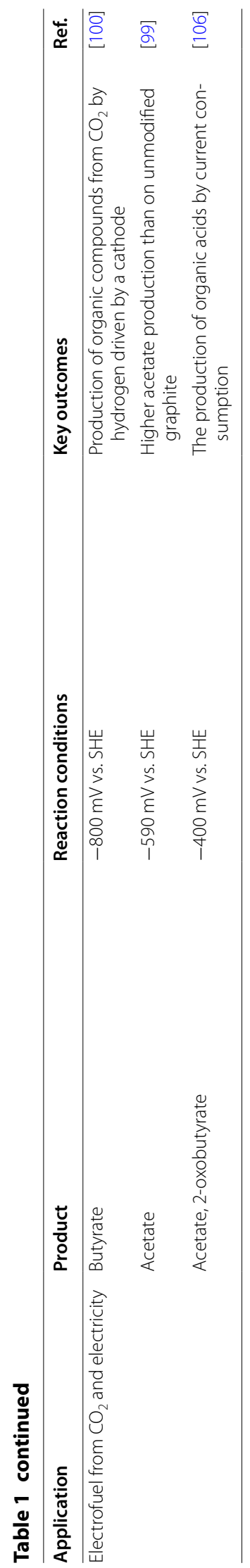


process in microbial metabolism. Direct electron transfer is ideal in extracellular electron transfer from a cathode to microbes.

The two mostly extensively studied microorganisms for extracellular electron transfer are Geobacter and Shewanella species. Geobacter and Shewanella are metal-reducing and gram-negative bacteria. Extracellular electron transfer in microorganisms is used in the metal reduction process by the microorganism and, in this case, the metal is used as an electron acceptor. When metal (hydr)oxides that are poorly soluble in water are present as electron acceptors, extracellular electron transfer occurs using multihaem c-type cytochromes in Geobacter and Shewanella [10]. Based on this phenomenon, the microorganisms are able to extracellularly transfer electrons and this can be applied for BES.

The mode of extracellular electron transfer is broadly divided into the following: (1) direct electron transfer: nanowire [11] or direct contact [12]; (2) mediators-shuttled: endogenous, exogenous as a redox compound or a by-product [13-15]; and (3) extracellular polymeric substances (EPS) of biofilms [16] (Fig. 1).

\section{Electron transfer from a cathode to microbes}

Multihame c-type cytochrome is a key component of the electron transfer channel in gram-negative bacteria [10]. Filamentous conductive pili are also involved in electron transfer in Shewanella [17] and Geobacter [11]. BES uses two directions, i.e., microbe $\rightarrow$ electrode (anode) in MFC and electrode (cathode) $\rightarrow$ microbe in MES, with the same or different mode. Electrons flow from an electron donor with a relatively lower redox potential to an electron acceptor with higher redox potential. In this light, in the present study we address the question that of whether it is possible to use the same electron transport chain for the opposite direction.

The redox tower in Fig. 2 shows the broad range of redox potential for MtrC (located on an extracellular site of the outer membrane), MrtA (a periplasmic c-type cytochrome), CymA (a link point between the inner membrane and the periplasm), and OmcA (anchored in the inner membrane), which were reported to play roles in electron transfer. It is proposed that reversible electron transfer within cytochrome c complex channels is feasible and the same electron transport chain can be used for the opposite direction.

\section{e-j $\rightarrow$ direct contact}

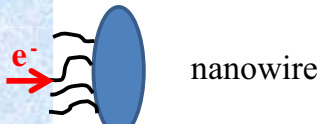

$\zeta$ Direct electron transfer

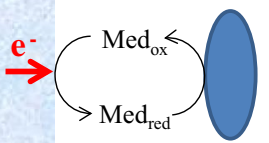

endogenous mediator shuttled

artificial mediator shuttled

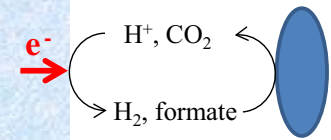

by-product shuttled

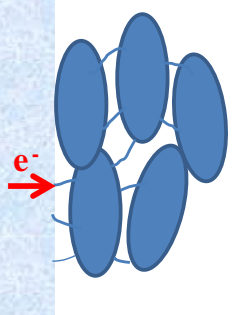

extracellular polymeric substances (EPS)

Fig. 1 Cathodic electron transfer mode. Electrons from a cathode flow into a microbe directly, through direct contact, nanowire, and endogenous mediator; or indirectly, through an artificial mediator, by-product, or EPS 


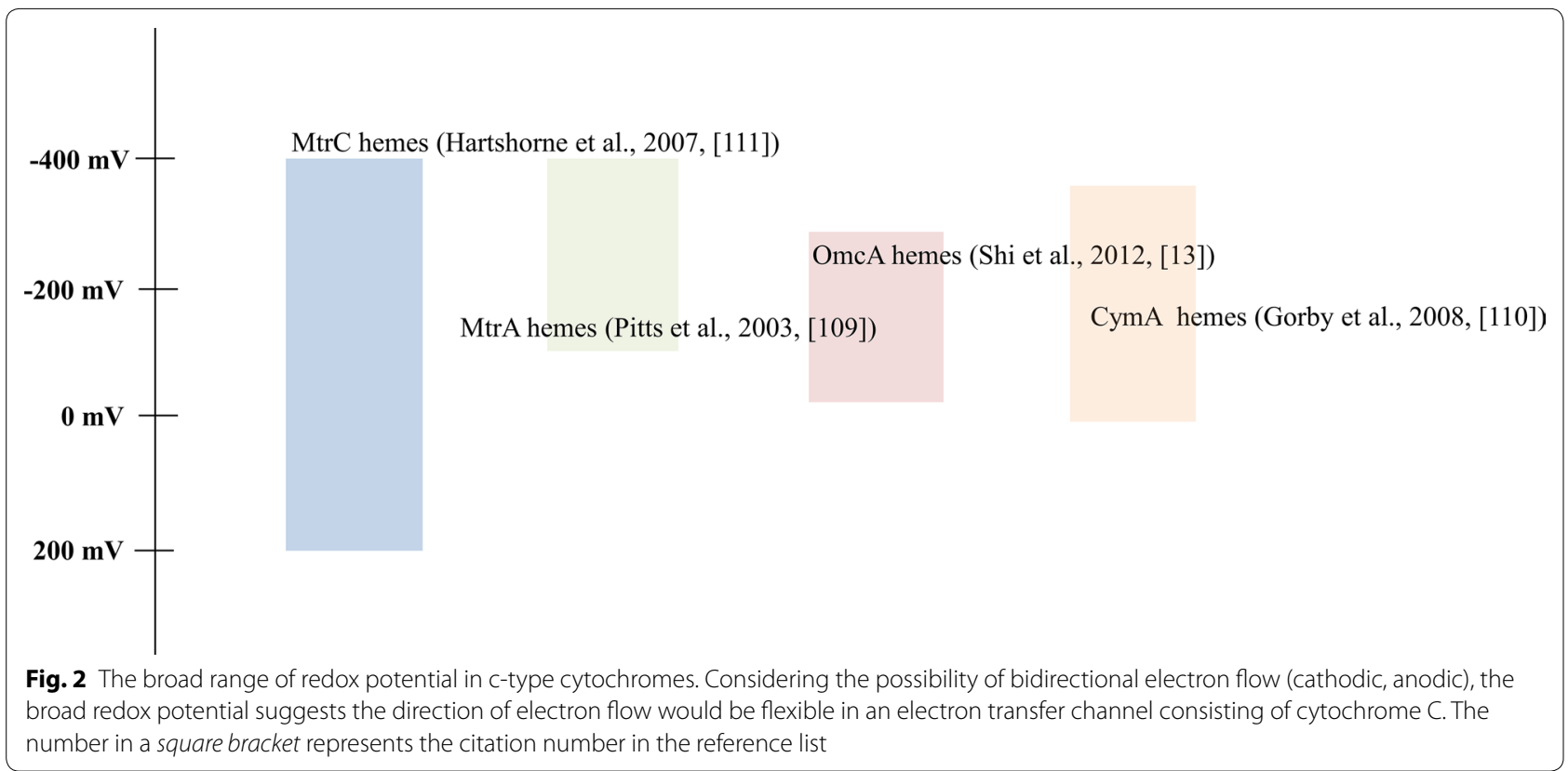

Extensively studied in MFC as iron-reducing bacteria, Shewanella oneidensis MR-1 [18] and Geobacter spp. [19] were reported to reduce the highly toxic hexavalent chromium $(\mathrm{Cr}(\mathrm{VI}))$ using a cathode. This indicates that both directions for electron transfer would be possible in current-producing bacteria, i.e., microbe $\rightarrow$ anode and cathode $\rightarrow$ microbe. However, it was reported that Shewanella showed a reversed Mtr pathway [20] but Geobacter used a different mode in the opposite direction [21].

Direct electron transfer from a cathode to microbes has been observed in a biocathode for microbial communities including betaproteobacteria $[22,23]$ and firmicutes [22], in addition to Shewanella and Geobacter. The presence of other electroactive, electron endergonic strains thus should be possible. Clostridium pasteurianum increased butanol production using cathode electron transfer without any mediator [24]. Nevertheless, the precise electron transfer channel for acceptance of extracellular electrons has not been verified; the redox enzyme in the membrane, however, may be involved in electrochemical reduction. Ferredoxin extracted from $C$. pasteurianum previously showed direct electrochemical reduction [25], but there is still no evidence of direct electron transfer through ferredoxin in whole cells. Also, several other redox proteins could be candidates for extracellular electron transfer.

\section{Predicted electron transfer proteins involved in extracellular electron transfer}

For direct electron transfer, a membrane-bound redox protein is needed. However, there has been no study of redox proteins involved in direct electron transfer except periplasmic c-type cytochrome. Several studies have reported the possibility of direct electron transfer by microorganisms in the absence of c-type cytochrome, and here we present some possible redox proteins involved in electron transfer channels including cytochromes (Table 2).

\section{Cytochrome}

The heme in cytochrome participates in electron transfer processes. Cell surface-localized cytochromes (OmcE and $\mathrm{OmcS}$ in Geobacter sulfurreducens, $\mathrm{MtrC}$ and $\mathrm{OmcA}$ in Shewanella oneidensis MR-1) are important components for electron transfer [26]. A microarray analysis of G. sulfurreducens gene transcript abundance showed the c-type cytochrome was highly expressed in currentproducing biofilms [21]. However, it was suggested that the mechanism of two opposite directions, i.e., microbe $\rightarrow$ electrode and electrode $\rightarrow$ microbe, would be significantly different in G. sulfurreducens. Recently, cytochrome $\mathrm{PccH}$ with a unusually low redox potential for cytochrome $(-24 \mathrm{mV}$ at $\mathrm{pH} 7)$ located in the periplasm was proposed as a candidate to provide electron 


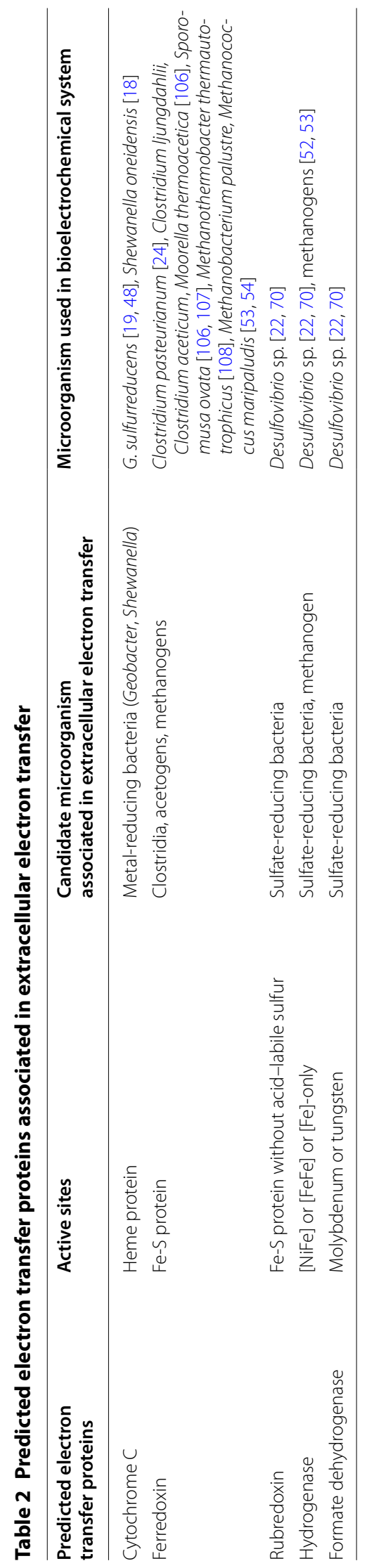


transfer in G. sulfurreducens, even though PccH could not be involved in the first step of accepting electrons [27, 28]. It is meanwhile known that S. oneidensis has a similar mechanism in both directions mainly using flavins (flavin mononucleotide and riboflavin) with cytochrome C [29].

\section{Ferredoxin: membrane-bound complex}

Rnf complexes (a membrane-bound NADH:ferredoxin oxidoreductase) are redox-driven ion pumps and have a membrane-bound, proton-translocating ferredoxin: $\mathrm{NAD}^{+}$oxidoreductase contributing to ATP synthesis (energy conservation) in acetogens such as Clostridium ljungdahlii. $\mathrm{RnF}$ is a multifunctional device with nitrogen fixation, proton translocation, and electron transport capabilities [30]. It is four flavin-containing cytoplasmatic multienzyme complexes from clostridia, acetogens, and methanogens [31] and so involved in flavin-based electron bifurcation (FBEB), which is regarded as a third mode of energy conservation in addition to substratelevel phosphorylation (SLP) and electron transport phosphorylation (ETP) [32]. Not all acetogens have rnf genes.

An energy-conserving hydrogenase (Ech) also plays a role in reducing ferredoxin with proton motive force [33]. It involves a coupling mechanism: an exergonic process attributes to coupled endergonic process; ferredoxin reduction with low potential as an exergonic reaction is coupled with $\mathrm{H}_{2}$ or NADH, a high-potential acceptor as endergonic reduction [34]. In methanogens, in the absence of cytochromes, methyltransferase is involved in a exergonic reaction to drive the extrusion of ions $\left(\mathrm{Na}^{+}\right.$ or $\mathrm{H}^{+}$) across the membrane [35]. In the context energy conservation in a bioelectrochemical system, electron supplementation from cathode would lead to FBEB. Electron bifurcating ferredoxin reduction $\mathrm{H}^{+}$gradient (for C. ljungdahlii) or $\mathrm{Na}^{+}$(for Acetobacterium woodii) via membrane-bound Rnf complex was supposed as key components in electron transport chain [36].

\section{Rubredoxin}

Rubredoxin (Rub) is also an electron transfer protein having a Fe-S cluster with relatively small molecules (about 55 amino acids) [37, 38]. It is one of the electron transfer components of sulfate-reducing bacteria (SRB) [39] and is also detected in Clostridium pasteurianum [37]. In Desulfovibrio vulgaris, Rub reduces hydrogen peroxide and superoxide [40]. Rub showed an electrochemical response with electrodes [41, 42]. Detailed roles of Rub in microorganisms have not been found but it is expected to be involved in an electron transfer channel.

\section{Hydrogenase and formate dehydrogenase}

It was recently reported that a hydrogenase and formate dehydrogenase, which are released from cells, are adsorbed onto electrodes to accept electrons in biocorrosion and bioelectrosynthesis [43]. Methyl viologenmediated electron transfer to hydrogenase from cathodes and mediatorless $\mathrm{H}_{2}$ production using cathodic electron transfer were previously suggested as electron transfer modes [44]. Formate dehydrogenase also showed direct electron transfer from cathodes [43, 45]. The periplasmic formate dehydrogenase transfers electrons to cytochrome $C$ in D. desulfuricans [46]. The combination of periplasmic enzyme and c-type cytochrome likely provides the electrical wiring [44]. Several membrane-bound enzymes such as fumarate reductase $[47,48]$ and a denitrification enzyme [49-51] led to bioelectrochemical reduction. Therefore, a periplasmic enzyme could be involved in an electron transfer channel in bioelectrochemical systems.

\section{Electroactive microorganisms Methanogens and acetogens}

The conversion of $\mathrm{CO}_{2}$ to $\mathrm{CH}_{4}$ was reported in a biocathode consisting of a methanogen via direct or indirect $\left(\mathrm{H}_{2}\right.$ mediator) channels [52-54]. The electron donor for methanogenesis is $\mathrm{H}_{2}$ for autotrophic methanogens or acetate for acetoclastic methanogens. It is supposed that, as in metal-reducing bacteria, the specific electron transfer channel in methanogens plays a role in extracellular electron transfer. Abiotically produced hydrogen is also used by methanogens in indirect electromethanogenesis, instead of direct cathodic electrons [55]. While no electron transfer channel involved in electron transfer from a cathode in methanogens has been identified, energy conservation by bifurcated electron transfer in methanogens could still potentially be found [56].

The study of enzyme purification and protein identification using mass spectroscopy in an acetotrophic methanogen, Methanosarcina acetivorans, showed that ferredoxin reduced membrane-associated multi-heme cytochrome c in Rnf $[57,58]$. Methanogens have membrane-associated hydrogenases using ferredoxin or methanophenazine as redox partners [59]. It was reported that hydrogenase and formate dehydrogenase released out of cells mediate electron transfer between a cathode and Methanococcus maripaludis [43]. Also, interspecies electron transfer was shown through flagellum-like appendages between Pelotomaculum thermopropionicum and Methanothermobacter thermoautotrophicus in the form of aggregates [5].

Several acetogenic bacteria (acetate production from $\mathrm{CO}_{2}$ and $\mathrm{H}_{2}$ ) including Sporomusa ovata, Sporomusa silvacetica, Sporomusa sphaeroides, Clostridium ljungdahlii, Clostridium aceticum, and Moorella thermoacetica consumed electrons from a cathode to reduce $\mathrm{CO}_{2}$ to acetate [60]. Recently, an acetogen closely related with Sporomusa sphaeroides was isolated and showed 
acetogenic growth using $\mathrm{Fe}(\mathrm{O})$ as a sole electron donor [61]. The acetogens Moorella thermoacetica and C. formicoaceticum reduced $\mathrm{CO}_{2}$ to formate, consuming electricity at the cathode compartment [62]. Although the mode of electron transfer to an electroactive acetogen from a cathode is still not known, the membrane-bound cytochromes and cobalt-containing corrinoids were suggested as candidates for an electron transfer channels [63]. Also, cytochrome-b enzymes (membrane-integral b-type cytochromes, $-0.215 \mathrm{~V}$ vs. SHE) were suggested to be involved in the electron transfer process of acetogens [64].

\section{Metal-oxidizing bacteria and sulfur-utilizing bacteria}

The ability of iron-reducing bacteria to give electrons anodes gave rise to the hypothesis that iron-oxidizing bacteria $(\mathrm{FeOB})$ could accept electrons from cathodes in two FeOB, Mariprofundus ferrooxydans and Rhodopseudomonas palustris, in recent studies [65-67] (Fig. 3). The marine isolate Mariprofundus ferrooxydans PV-1 used a cathode as a sole electron donor, generated ATP, and fixed $\mathrm{CO}_{2}$ [67]. Rhodopseudomonas palustris TIE-1 accepted electrons from a cathode, independent of photosynthesis. The dark current indicated extracellular electron uptake uncoupled from the cyclic photosynthetic apparatus and the pioABC operon influenced electron uptake [65]. Rhodopseudomonas palustris TIE-1 increased electron uptake rate 56-fold with unlimited $\mathrm{Fe}(\mathrm{II})$ supplementation in a photobioelectrochemical system [67].

It was reported that isolated marine corrosive delta proteobacterial SRB used elemental iron as the sole electron donor and reduced sulfate, showing the possibility of extracellular electron transfer [68]. Recently, a sulfideoxidizing bacteria, Desulfobulbaceae, was reported to reduce oxygen in the upper layers of marine sediments using centimeter-long filaments [69]. For removal of $\mathrm{H}_{2} \mathrm{~S}$, the product of sulfate reduction and a toxic gas to oxygen-consuming organisms, sulfide-oxidizing bacteria used oxygen as an electron acceptor using filaments as electrical cables for $\mathrm{H}_{2} \mathrm{~S}$ oxidation to $\mathrm{S}$ [69].

The SRB reduced acetate, butyrate to ethanol, butanol, respectively, using electrons through direct electron transfer from a cathode [70]. It was suggested that the direct electron transfer could take place via a redox enzyme such as cytochrome-b in SRB [70]. The SRB Desulfopila corrodens strain IS4 showed direct electron transfer affecting iron corrosion. Electrochemical and infrared spectroelectrochemical analyses indicated c-type cytochromes were involved in electron transfer [71]. Acidithiobacillus ferrooxidans, Desulfosporosinus orientis, Thiobacillus denitrificans, Sulfurimonas denitrificans, and Desulfovibrio piger also showed electroactivity to accept electrons from a cathode in pure cultures [72].

\section{Cathode modification for enhanced performance of bioelectrochemical reduction}

Efforts to improve the efficiency of electron transfer between a cathode and microorganisms have focused on increasing of the interfacial area and interfacial interactions. Nanoparticle attachment on a cathode was attempted with nano-nickel [73], carbon nanotubes [74, 75], conjugated oligoelectrolytes (COEs) [76], and carbon nanotubes on reticulated vitreous carbon (NanoWebRVC) [74, 77]. Also, a graphene-modified biocathode enhanced bioelectrochemical production of hydrogen in a MES system [78].

Another attempt involved positively charged surface modification. Extracellular electron transfer from a cathode to a microbe was increased using a positively charged

\section{Exoelectrogen}

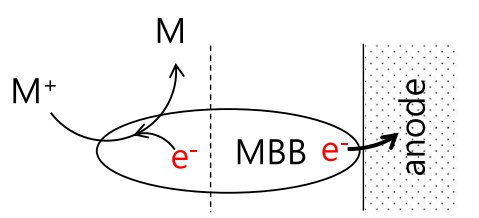

Microbe Metal-reducing bacteria (MBB)

Electron flow Microbe $\rightarrow$ anode
Endoelectrogen

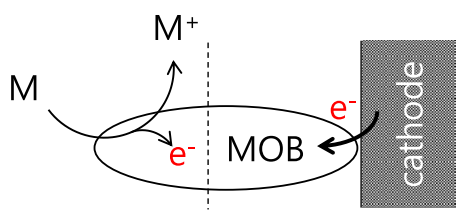

Metal-oxidizing bacteria (MOB)

Application Current production

Current consumption

Fig. 3 Analogy between metal-utilizing bacteria and direct extracellular electron transfer in a bioelectrochemical system. The left side of the dotted line shows the electron flow with metals in metal-utilizing bacteria and the right side indicates interaction with the electrode 
functional group on the surface of a cathode [74]. Negatively charged $S$. ovate preferred to attach on a cathode and enhanced acceptance of electrons from the cathode for the reduction of $\mathrm{CO}_{2}$ to acetate [74]. The positively charged anode led to an enriched biofilm on an anode but the negatively charged cathode has a repulsive interaction with microorganisms because the cell walls of most bacteria have an overall net negative charge. Therefore, attachment with microorganisms on a cathode has a charge barrier and one study showed that both the zeta potential and the hydrophobicity of cells increased in a current-consuming biofilm [24]. Modification should be tried according to the changes of cell surface characteristics on a cathode, in contrast with on an anode.

\section{Application for valuable biofuel production}

A study of the life cycle assessment (LCA) showed MFCs do not give environmental benefit relative to the conventional anaerobic treatment [79]. The development of the MEC system connected with valuable product formation was suggested for positive energy gain $[79,80]$. Thus, the product developments using bioelectrochemical reaction between microbe-cathode are promising research directions.

\section{Metabolic shift to reduced compound production (electrofermentation)}

Electron transfer via an artificial mediator from a cathode has been applied in several studies and it showed an increase of reduced compound production [15, 81-85].
The distribution of final products would be determined by the electron and carbon flow in the fermentation process. Therefore, it is important to control the electron/ carbon flow accordingly for production of the targeted bioproduct. Recently, an increase of butanol production in C. pasteurianum in a bioelectrochemical system showed the reducing power from a cathode could shift the metabolic pathway to solvent production [24]. The supplement of electrons via the cathode into a microbe led to enhanced reduction reaction directly (working on surface-associated redox enzymes, such as hydrogenases and presumably dehydrogenases [43]) or indirectly (increasing a reduced cofactor such as NADH, Fig. 4). The direct reduction process was studied in fumarate reduction to succinate [47], nitrate reduction to nitrite [48], nitrobenzene reduction to aniline [86], and hexavalent chromium reduction [18]. The indirect reduction process includes ethanol production from acetate [81], alcohol formation from glycerol [87], and butyraldehyde to butanol [88].

\section{Reduction for value-added bioproducts: chain elongation}

The interaction between a cathode and microbes led to reverse $\beta$ oxidation [89] and reduced propionate (C3) to valerate $(\mathrm{C} 5)$ in a glycerol-fed bioelectrochemical system [87]. Without fermentable substrates, the reduction of acetate (C2) to caproate (C6) and caprylate (C8) took place in a Clostridium kluyveri-predominant mixed culture in a bioelectrochemical system at $-0.9 \mathrm{~V}$ vs. NHE cathode potential using in-situ produced hydrogen as

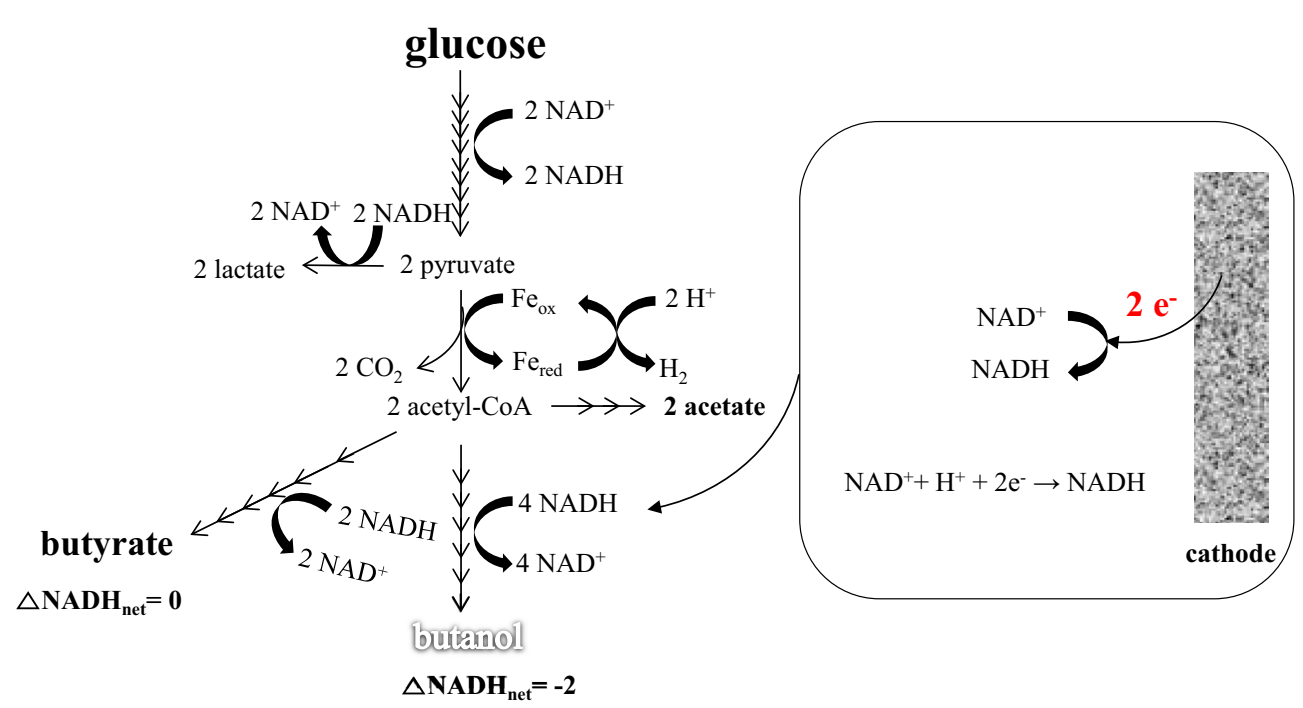

Fig. 4 The microbial metabolic pathway of $\mathrm{NADH}$-consuming compound production. One arrow indicates one step of reaction. The butyrate is $\mathrm{NADH}$-balanced and generally produced more than butanol. The NADH reduction (inset) by electricity increases the flux of electron for butanol formation, more $\mathrm{NADH}$-consuming pathway. $\triangle \mathrm{NADH}_{\text {net }}$ (per one mol of product) $=\mathrm{NADH}$ production - NADH consumption, $\mathrm{Fe}_{\mathrm{ox}}$ oxidized form of ferredoxin, $\mathrm{Fe}_{\text {red }}$ reduced form of ferredoxin 
an electron donor [90]. The reduction of acetate (C2) and butyrate $(\mathrm{C} 4)$ into alcohols $(\mathrm{C} 1 \sim \mathrm{C} 4)$, acetone $(\mathrm{C} 2)$ and caproate (C6) occurred in a mixed culture of SRB at a potential of $-0.85 \mathrm{~V}$ vs. $\mathrm{Ag} / \mathrm{AgCl}$ via direct electron transfer [70].

The application of a cathode for additional reducing power can improve low-grade chemicals to valuable biofuels with energy supplement through the reduction process of an acid to alcohol or by chain elongation. In particular, landfill leachate, which contains acetate, propionate, and butyrate as main components [91], could be used as feed stocks in bioelectrochemical systems to upgrade waste to value-added biofuels, for examples, acetate to butanol [92] (Fig. 5), glycerol to 1,3-propandiol [93], glucose to polyhydroxyalkanoates (PHA) [92].

\section{Electrofuel production ( $\mathrm{CO}_{2}$ fixation)}

Various electron sources can be used as electron donors (organic compounds, $\mathrm{H}_{2}, \mathrm{H}_{2} \mathrm{O}$, etc.) or acceptors $\left(\mathrm{O}_{2}\right.$, metal, $\mathrm{CO}_{2}$, etc.) by microbial organisms, whereas humans only use organic carbon as an electron donor and $\mathrm{O}_{2}$ as an electron acceptor. BES uses an electrode as an electron donor (cathode) or an electron acceptor (anode). In particular, electrofuel is a carbon fixation process using a cathode as an electron donor and $\mathrm{CO}_{2}$ as a carbon source, and this process mimics natural photosynthesis in plants [95-97].

$$
n \mathrm{CO}_{2}+(6 n+2)\left(e^{-1}+\mathrm{H}^{+}\right) \rightarrow \mathrm{C}_{n} \mathrm{H}_{2 n+2}+2 n \mathrm{H}_{2} \mathrm{O}
$$

Electrofuel has several advantages: (1) the $\mathrm{CO}_{2}$ greenhouse gas can be used as a substrate, and the efficiency of the electricity to chemical commodities is relatively high $(80 \sim 90 \%)$, i.e., more efficient than photosynthesis; (2) the electricity can be from many renewable sources; and (3) it has good specificity to produce desired chemical commodities. However, research in this ara is an early stage and the final titer is low and the $\mathrm{CO}_{2}$ reduction rate is slow [98].

An acetogen used an electrode as an electron source to produce 2-oxobutyrate as well as acetate [60]. The longterm operation of a bioelectrochemical system with $\mathrm{CO}_{2}$ produced acetate at a level of $10.5 \mathrm{~g} / \mathrm{L}$ over 20 days [99]. However, the concentration of other carbon compounds was still small, such as butyrate $35 \mathrm{mg} / \mathrm{L}$ [100], isobutanol $846 \mathrm{mg} / \mathrm{L}$, and 3-methyl-a-butanol $570 \mathrm{mg} / \mathrm{L}$ [13].

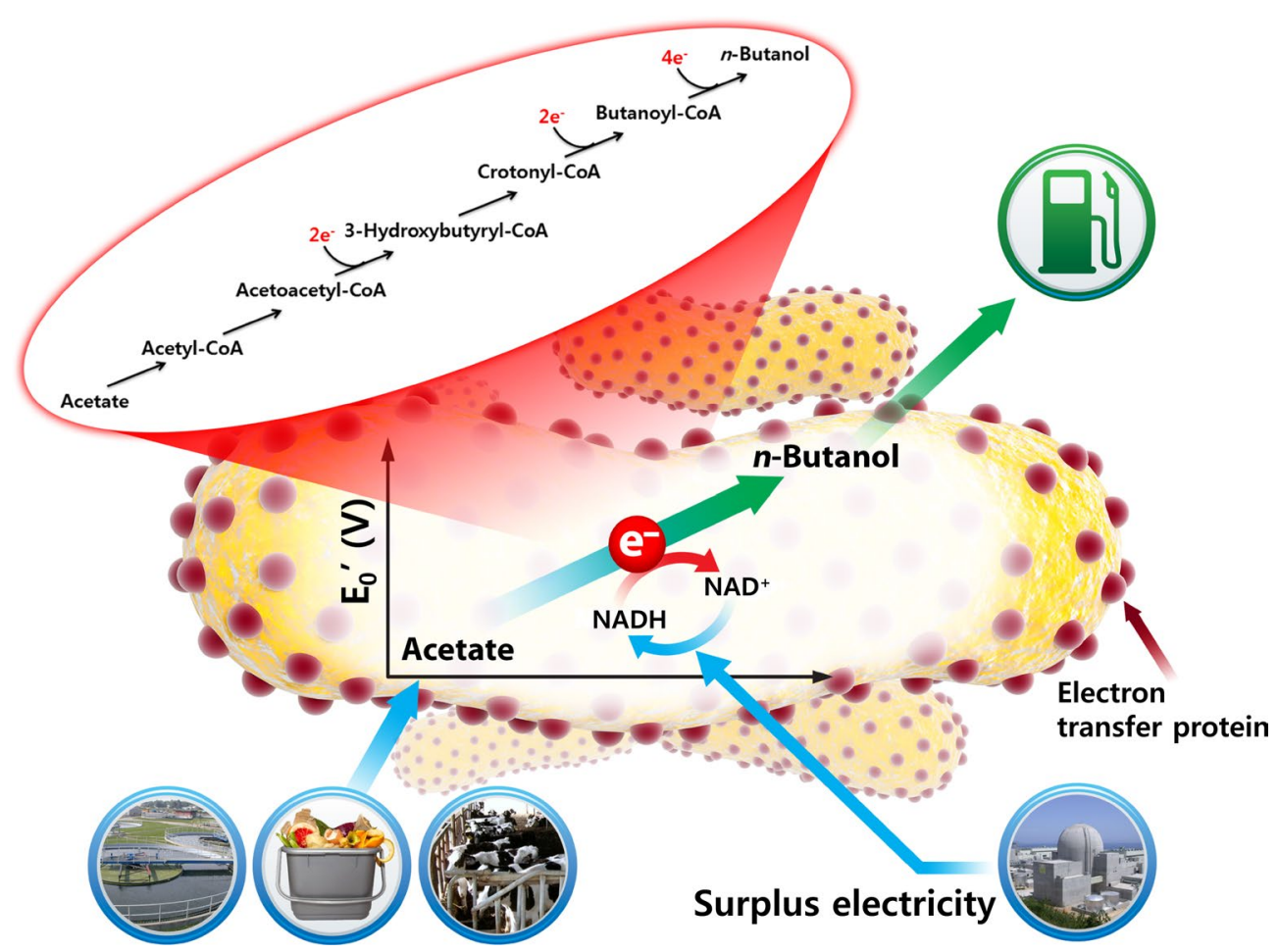

Fig. 5 The upgrade of waste into value-added biofuels. The acetate from wastes, such as waste activated sludge, food waste, and animal manure, was feed stocks for biofuel production by electroactive microorganisms. The extracellular electron transfer from cathode to microbe via electron transfer protein could be used for the reduction of acetate to butanol. NADH the reduced form, $\mathrm{NAD}^{+}$the oxidized form of nicotinamide adenine dinucleotide, respectively 


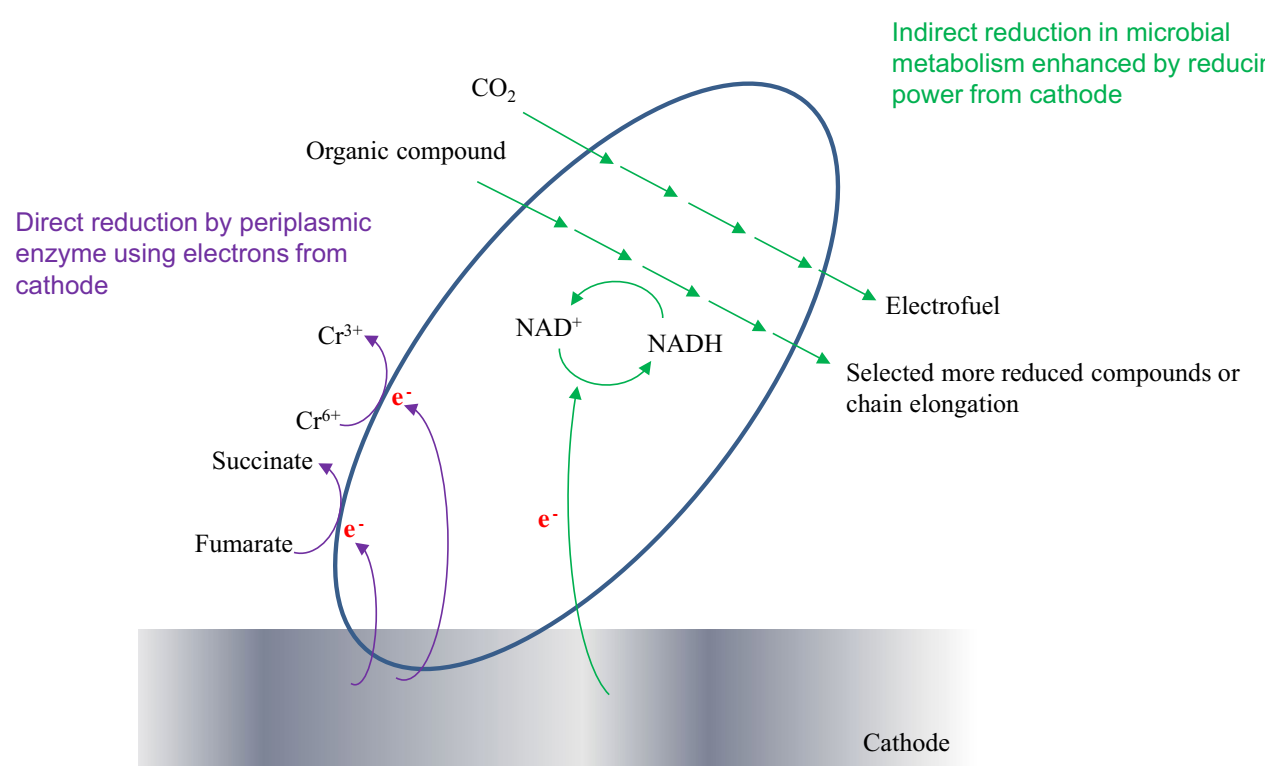

Fig. 6 The application of bioelectrochemical reduction for cathodic electron transfer from a cathode to a microbe

In the absence of direct electron transfer, hydrogen led the reduction process with a hybrid microbial-watersplitting catalyst system [13, 101]. The hydrogen from water splitting was used to reduce carbon dioxide to produce liquid fuels and engineered Ralstonia eutropha produced isopropanol up to $216 \mathrm{mg} / \mathrm{L}$ [101]. Fermentative hydrogen production enhanced at $-0.6 \mathrm{~V}$ vs. SHE led to increased 1,3-propandiol production [93]. Electrochemical generation of formate also mediated electron supplementation to microbes from a cathode in BES [13].

\section{Conclusions}

The cathodic reaction in BES is of increasing concern in the context of producing alternative fuels. Beginning with metal-utilizing bacteria, several electroactive bacteria were found and applied for the conversion of electrical to chemical energy as biofuels or biotransformation (Fig. 6). Nonetheless, many technical challenges must still be addressed and the titer of final product is also low. However, research is still in an early stage and efforts such as cell membrane modification and cathode surface modification would enhance the efficiency of BES, as shown in previous studies on MFC.

\section{Abbreviations}

BES: bioelectrochemical synthesis; COEs: conjugated oligoelectrolytes; Ech: energy-conserving hydrogenase; EPS: extracellular polymeric substances; ETP: electron transport phosphorylation; FBEB: flavin-based electron bifurcation; FeOB: iron-oxidizing bacteria; MES: microbial electrosynthesis; MFC: microbial fuel cells; Rub: Rubredoxin; RVC: reticulated vitreous carbon; SHE: standard hydrogen electrode; SLP: substrate-level phosphorylation; SRB: sulfate-reducing bacteria.

\section{Authors' contributions}

$\mathrm{OC}$ and BIS conceptualized the manuscript. OC was responsible for literature review, data acquisition and analysis, and initial writing. BIS contributed with review and editing. Both authors read and approved the final manuscript.

\section{Acknowledgements}

This work was supported by the research fund of the Korean Ministry of Environment as "Converging Technology Project (202-101-006)" and the Korea Government Ministry of Trade, Industry and Energy as "the New \& Renewable Energy of the Korea Institute of Energy Technology Evaluation and Planning (KETEP, No. 20133030000300)."

\section{Competing interests}

The authors declare that they have no competing interests.

Received: 28 July 2015 Accepted: 5 January 2016

Published online: 19 January 2016

\section{References}

1. Li H, Liao JC. Biological conversion of carbon dioxide to photosynthetic fuels and electrofuels. Energ Environ Sci. 2013;6(10):2892-9. doi:10.1039/C3EE41847B.

2. Hawkins AS, Han Y, Lian H, Loder AJ, Menon AL, Iwuchukwu IJ, et al. Extremely thermophilic routes to microbial electrofuels. Acs Catalysis. 2011;1(9):1043-50.

3. Schroder U, Harnisch F, Angenent LT. Microbial electrochemistry and technology: terminology and classification. Energ Environ Sci. 2015;8(2):513-9. doi:10.1039/C4EE03359K.

4. Smith JA, Nevin KP, Lovley DR. Syntrophic growth via quinonemediated interspecies electron transfer. Front in Microbiol. 2015;6:121. doi:10.3389/fmicb.2015.00121.

5. Si Ishii, Kosaka T, Hori K, Hotta Y, Watanabe K. Coaggregation facilitates interspecies hydrogen transfer between Pelotomaculum thermopropionicum and Methanothermobacter thermautotrophicus. Appl Environ Microbiol. 2005;71(12):7838-45. doi:10.1128/aem.71.12.7838-7845.2005.

6. Pous N, Casentini B, Rossetti S, Fazi S, Puig S, Aulenta F. Anaerobic arsenite oxidation with an electrode serving as the sole electron acceptor: a 
novel approach to the bioremediation of arsenic-polluted groundwater. J Hazard Mater. 2015;283:617-22. doi:10.1016/j.jhazmat.2014.10.014.

7. Stams AJM, De Bok FAM, Plugge CM, Van Eekert MHA, Dolfing J, Schraa G. Exocellular electron transfer in anaerobic microbial communities. Environ Microbiol. 2006;8(3):371-82. doi:10.1111/j.1462-2920.2006.00989.x.

8. Kim T, Kim B. Electron flow shift in Clostridium acetobutylicum fermentation by electrochemically introduced reducing equivalent. Biotechnol Lett. 1988;10(2):123-8. doi:10.1007/BF01024638.

9. Vasconcelos I, Girbal L, Soucaille P. Regulation of carbon and electron flow in Clostridium acetobutylicum grown in chemostat culture at neutral pH on mixtures of glucose and glycerol. J Bacteriol. 1994;176(5):1443-50. doi:10.1128/JB.183.5.1748-1754.2001.

10. Shi L, Squier TC, Zachara JM, Fredrickson JK. Respiration of metal (hydr)oxides by Shewanella and Geobacter: a key role for multihaem c-type cytochromes. Mol Microbiol. 2007;65(1):12-20. doi:10.1111/j.1365-2958.2007.05783.x.

11. Reguera G, McCarthy KD, Mehta T, Nicoll JS, Tuominen MT, Lovley DR. Extracellular electron transfer via microbial nanowires. Nature. 2005;435(7045):1098-101. doi:10.1038/nature03661.

12. Myers CR, Myers JM. Localization of cytochromes to the outer membrane of anaerobically grown Shewanella putrefaciens MR-1. J Bacteriol. 1992;174(11):3429-38.

13. Shi L, Rosso KM, Clarke TA, Richardson DJ, Zachara JM, Fredrickson JK. Molecular Underpinnings of Fe(III) Oxide Reduction by Shewanella Oneidensis MR-1. Front Microbiol. 2012;3:50. doi:10.3389/fmicb.2012.00050.

14. Marsili E, Baron DB, Shikhare ID, Coursolle D, Gralnick JA, Bond DR. Shewanella secretes flavins that mediate extracellular electron transfer. Proc Natl Acad Sci. 2008;105(10):3968-73. doi:10.1073/pnas.0710525105.

15. Choi O, Um Y, Sang B-I. Butyrate production enhancement by Clostridium tyrobutyricum using electron mediators and a cathodic electron donor. Biotechnol Bioeng. 2012;109(10):2494-502. doi:10.1002/ bit.24520.

16. Cao B, Shi L, Brown RN, Xiong Y, Fredrickson JK, Romine MF, et al. Extracellular polymeric substances from Shewanella sp. HRCR-1 biofilms: characterization by infrared spectroscopy and proteomics. Environ Microbiol. 2011;13(4):1018-31. doi:10.1111/j.1462-2920.2010.02407.x.

17. Gorby YA, Yanina S, McLean JS, Rosso KM, Moyles D, Dohnalkova A, et al. Electrically conductive bacterial nanowires produced by Shewanella oneidensis strain MR-1 and other microorganisms. Proc Natl Acad Sci. 2006;103(30):11358-63. doi:10.1073/pnas.0604517103.

18. Xafenias N, Zhang Y, Banks CJ. Enhanced performance of hexavalent chromium reducing cathodes in the presence of Shewanella oneidensis MR-1 and lactate. Environ Sci Technol. 2013;47(9):4512-20. doi:10.1021/ es304606u.

19. Gregory KB, Lovley DR. Remediation and recovery of uranium from contaminated subsurface environments with electrodes. Environ Sc Technol. 2005;39(22):8943-7. doi:10.1021/es050457e.

20. Ross DE, Flynn JM, Baron DB, Gralnick JA, Bond DR. Towards electrosynthesis in Shewanella: energetics of reversing the Mtr pathway for reductive metabolism. PLoS One. 2011;6(2):e16649. doi:10.1371/journal. pone.0016649.

21. Strycharz SM, Glaven RH, Coppi MV, Gannon SM, Perpetua LA, Liu A, et al. Gene expression and deletion analysis of mechanisms for electron transfer from electrodes to Geobacter sulfurreducens. Bioelectrochemistry. 2011;80(2):142-50. doi:10.1016/j.bioelechem.2010.07.005.

22. Croese E, Pereira M, Euverink G-J, Stams AM, Geelhoed J. Analysis of the microbial community of the biocathode of a hydrogen-producing microbial electrolysis cell. Appl Microbiol Biotechnol. 2011;92(5):108393. doi:10.1007/s00253-011-3583-X.

23. Chen G-W, Choi S-J, Lee T-H, Lee G-Y, Cha J-H, Kim C-W. Application of biocathode in microbial fuel cells: cell performance and microbial community. Appl Microbiol Biotechnol. 2008;79(3):379-88. doi:10.1007/ s00253-008-1451-0.

24. Choi O, Kim T, Woo HM, Um Y. Electricity-driven metabolic shift through direct electron uptake by electroactive heterotroph Clostridium pasteurianum. Sci Rep. 2014; doi:10.1038/srep06961.

25. Armstrong FA, Hill HAO, Walton NJ. Direct electrochemical reduction of ferredoxin promoted by Mg2+. FEBS Lett. 1982;145(2):241-4. doi:10.1016/0014-5793(82)80175-0.
26. Shi L, Richardson DJ, Wang Z, Kerisit SN, Rosso KM, Zachara JM, et al. The roles of outer membrane cytochromes of Shewanella and Geobacter in extracellular electron transfer. Environ Microbiol Rep. 2009;1(4):220-7. doi:10.1111/j.1758-2229.2009.00035.x.

27. Dantas JM, Campelo LM, Duke NEC, Salgueiro CA, Pokkuluri PR. The structure of PccH from Geobacter sulfurreducens: A novel low reduction potential monoheme cytochrome essential for accepting electrons from an electrode. FEBS J. 2015:n/a-n/a. doi:10.1111/febs.13269.

28. Dantas JM, Tomaz DM, Morgado L, Salgueiro CA. Functional characterization of $\mathrm{PcCH}$, a key cytochrome for electron transfer from electrodes to the bacterium Geobacter sulfurreducens. FEBS Lett. 2013;587(16):2662-8. doi:10.1016/j.febslet.2013.07.003.

29. Sydow A, Krieg T, Mayer F, Schrader J, Holtmann D. Electroactive bacteria-molecular mechanisms and genetic tools. Appl Microbiol Biotechnol. 2014;98(20):8481-95. doi:10.1007/s00253-014-6005-z.

30. Tremblay PL, Zhang T, Dar SA, Leang C, Lovley DR. The Rnf complex of Clostridium ljungdahlii is a proton-translocating ferredoxin:nAD ${ }^{+}$oxidoreductase essential for autotrophic growth. MBio. 2012;4(1):e0040612. doi:10.1128/mBio.00406-12.

31. Chowdhury NP, Mowafy AM, Demmer JK, Upadhyay V, Koelzer S, Jayamani $\mathrm{E}$, et al. Studies on the mechanism of electron bifurcation catalyzed by electron transferring flavoprotein (Etf) and butyryl-CoA dehydrogenase (Bcd) of Acidaminococcus fermentans. J Biol Chem. 2014;289(8):5145-57. doi:10.1074/jbc.M113.521013.

32. Buckel W, Thauer RK. Energy conservation via electron bifurcating ferredoxin reduction and proton/ $\mathrm{Na}(+)$ translocating ferredoxin oxidation. Biochim Biophys Acta. 2013;1827(2):94-113. doi:10.1016/j. bbabio.2012.07.002

33. Hess V, Poehlein A, Weghoff MC, Daniel R, Muller V. A genome-guided analysis of energy conservation in the thermophilic, cytochromefree acetogenic bacterium Thermoanaerobacter kivui. BMC Genom. 2014;15:1139. doi:10.1186/1471-2164-15-1139.

34. Lane N, Martin William F. The origin of membrane bioenergetics. Cell. 2012;151(7):1406-16. doi:10.1016/j.cell.2012.11.050.

35. Bertsch J, Oppinger C, Hess V, Langer JD, Muller V. Heterotrimeric $\mathrm{NADH}$-oxidizing methylenetetrahydrofolate reductase from the acetogenic bacterium Acetobacterium woodii. J Bacteriol. 2015;197(9):16819. doi:10.1128/jb.00048-15.

36. Kracke F, Vassilev I, Krömer JO. Microbial electron transport and energy conservation - the foundation for optimizing bioelectrochemical systems. Front Microbiol. 2015. doi:10.3389/fmicb.2015.00575.

37. Lovenberg W, Sobel BE. Rubredoxin: a new electron transfer protein from Clostridium pasteurianum. P Natl Acad Sci USA. 1965;54(1):193-9

38. Park I, Youn B, Harley J, Eidsness M, Smith E, Ichiye T, et al. The unique hydrogen bonded water in the reduced form of Clostridium pasteurianum rubredoxin and its possible role in electron transfer. JBIC, J Biol Inorg Chem. 2004;9(4):423-8. doi:10.1007/s00775-004-0542-3.

39. Bruschi M, Hatchikian CE, Golovleva LA, Gall JL. Purification and characterization of cytochrome c3, ferredoxin, and rubredoxin isolated from Desulfovibrio desulfuricans Norway. J Bacteriol. 1977;129(1):30-8.

40. Coulter ED, Kurtz DM Jr. A role for rubredoxin in oxidative stress protection in Desulfovibrio vulgaris: catalytic electron transfer to rubrerythrin and two-iron superoxide reductase. Arch Biochem Biophys. 2001;394(1):76-86. doi:10.1006/abbi.2001.2531.

41. Correia dos Santos MM, Paes de Sousa PM, Simões Gonçalves ML, Krippahl L, Moura JJG, Lojou É, et al. Electrochemical studies on small electron transfer proteins using membrane electrodes. J Electroanal Chem. 2003;541:153-62. doi:10.1016/S0022-0728(02)01427-4.

42. dos Correia Santos MM, de Paes Sousa PM, Simões Gonçalves ML, Ascenso C, Moura I, Moura JJG. Electrochemical studies of rubredoxin from Desulfovibrio vulgaris at modified electrodes. J Electroanal Chem. 2001;501(1-2):173-9. doi:10.1016/S0022-0728(00)00521-0.

43. Deutzmann JS, Sahin M, Spormann AM. Extracellular enzymes facilitate electron uptake in biocorrosion and bioelectrosynthesis. mBio. 2015;6(2). doi:10.1128/mBio.00496-15.

44. Rosenbaum M, Aulenta F, Villano M, Angenent LT. Cathodes as electron donors for microbial metabolism: which extracellular electron transfer mechanisms are involved? Biores Technol. 2011;102(1):324-33. doi:10.1016/j.biortech.2010.07.008. 
45. Srikanth S, Maesen M, Dominguez-Benetton X, Vanbroekhoven K, Pant D. Enzymatic electrosynthesis of formate through $\mathrm{CO}_{2}$ sequestration/reduction in a bioelectrochemical system (BES). Biores Technol. 2014;165:350-4. doi:10.1016/j.biortech.2014.01.129.

46. da Silva SM, Pacheco I, Pereira IA. Electron transfer between periplasmic formate dehydrogenase and cytochromes c in Desulfovibrio desulfuricans ATCC 27774. J Biol Inorg Chem. 2012;17(5):831-8. doi:10.1007/ s00775-012-0900-5.

47. Dumas C, Basseguy R, Bergel A. Microbial electrocatalysis with Geobacter sulfurreducens biofilm on stainless steel cathodes. Electrochim Acta. 2008;53(5):2494-500. doi:10.1016/j.electacta.2007.10.018.

48. Gregory KB, Bond DR, Lovley DR. Graphite electrodes as electron donors for anaerobic respiration. Environ Microbiol. 2004;6(6):596-604. doi:10.1111/j.1462-2920.2004.00593.x.

49. Virdis B, Read ST, Rabaey K, Rozendal RA, Yuan Z, Keller J. Biofilm stratification during simultaneous nitrification and denitrification (SND) at a biocathode. Biores Technol. 2011;102(1):334-41. doi:10.1016/j. biortech.2010.06.155.

50. Desloover J, Puig S, Virdis B, Clauwaert P, Boeckx P, Verstraete W, et al. Biocathodic nitrous oxide removal in bioelectrochemical systems. Environ Sci Technol. 2011;45(24):10557-66. doi:10.1021/es202047x.

51. Pous N, Puig S, Dolors Balaguer M, Colprim J. Cathode potential and anode electron donor evaluation for a suitable treatment of nitratecontaminated groundwater in bioelectrochemical systems. Chem. Eng J. 2015;263:151-9. doi:10.1016/j.cej.2014.11.002.

52. Villano M, Aulenta F, Ciucci C, Ferri T, Giuliano A, Majone M. Bioelectrochemical reduction of $\mathrm{CO}_{2}$ to $\mathrm{CH}_{4}$ via direct and indirect extracellular electron transfer by a hydrogenophilic methanogenic culture. Biores Technol. 2010;101(9):3085-90. doi:10.1016/j.biortech.2009.12.077.

53. Cheng S, Xing D, Call DF, Logan BE. Direct biological conversion of electrical current into methane by electromethanogenesis. Environ Sci Technol. 2009;43(10):3953-8. doi:10.1021/es803531g.

54. Lohner ST, Deutzmann JS, Logan BE, Leigh J, Spormann AM. Hydrogenase-independent uptake and metabolism of electrons by the archaeon Methanococcus maripaludis. ISME J. 2014;8(8):1673-81. doi:10.1038/ismej.2014.82.

55. Hara M, Onaka Y, Kobayashi H, Fu Q, Kawaguchi H, Vilcaez J, et al. Mechanism of electromethanogenic reduction of $\mathrm{CO}_{2}$ by a thermophilic methanogen. Energy Procedia. 2013;37:7021-8. doi:10.1016/j. egypro.2013.06.637.

56. Costa KC, Wong PM, Wang T, Lie TJ, Dodsworth JA, Swanson I, et al. Protein complexing in a methanogen suggests electron bifurcation and electron delivery from formate to heterodisulfide reductase. Proc Natl Acad Sci. 2010;107(24):11050-5. doi:10.1073/pnas.1003653107.

57. Wang $M$, Tomb J-F, Ferry J. Electron transport in acetate-grown Methanosarcina acetivorans. BMC Microbiol. 2011;11(1):165. doi:10.1186/1471-2180-11-165

58. Schlegel K, Welte C, Deppenmeier U, Müller V. Electron transport during aceticlastic methanogenesis by Methanosarcina acetivorans involves a sodium-translocating Rnf complex. FEBS J. 2012;279(24):4444-52. doi:10.1111/febs.12031.

59. Thauer RK, Kaster A-K, Goenrich M, Schick M, Hiromoto T, Shima S. Hydrogenases from methanogenic Archaea, nickel, a novel cofactor, and $\mathrm{H}_{2}$ Storage. Annu Rev Biochem. 2010;79(1):507-36. doi:10.1146/ annurev.biochem.030508.152103.

60. Nevin KP, Hensley SA, Franks AE, Summers ZM, Ou J, Woodard TL, et al. Electrosynthesis of organic compounds from carbon dioxide is catalyzed by a diversity of acetogenic microorganisms. Appl Environ Microbiol. 2011;77(9):2882-6. doi:10.1128/aem.02642-10.

61. Kato S, Yumoto I, Kamagata Y. Isolation of acetogenic bacteria that induce biocorrosion by utilizing metallic iron as the sole electron donor. Appl Environ Microbiol. 2015;81(1):67-73. doi:10.1128/aem.02767-14.

62. Song J, Kim Y, Lim M, Lee H, Lee Jl, Shin W. Microbes as electrochemical $\mathrm{CO}_{2}$ conversion catalysts. ChemSusChem. 2011;4(5):587-90. doi:10.1002/cssc.201100107.

63. Xafenias N, Mapelli V. Performance and bacterial enrichment of bioelectrochemical systems during methane and acetate production. Int J Hydrogen Energ. 2014;39(36):21864-75. doi:10.1016/j. ijhydene.2014.05.038.

64. Müller V. Energy conservation in acetogenic bacteria. Appl Environ Microbiol. 2003;69(11):6345-53. doi:10.1128/aem.69.11.6345-6353.2003.
65. Bose A, Gardel EJ, Vidoudez C, Parra EA, Girguis PR. Electron uptake by iron-oxidizing phototrophic bacteria. Nat Commun. 2014. doi:10.1038/ ncomms4391.

66. Doud DFR, Angenent LT. Toward electrosynthesis with uncoupled extracellular electron uptake and metabolic growth: enhancing current uptake with Rhodopseudomonas palustris. Environ Sci Technol Lett. 2014:1(9):351-5. doi:10.1021/ez500244n.

67. Summers ZM, Gralnick JA, Bond DR. Cultivation of an obligate fe(ii)oxidizing lithoautotrophic bacterium using electrodes. mBio. 2013;4(1). doi:10.1128/mBio.00420-12.

68. Dinh HT, Kuever J, Muszmann M, Hassel AW, Stratmann M, Widdel F. Iron corrosion by novel anaerobic microorganisms. Nature. 2004;427(6977):829-32. doi:10.1038/nature02321.

69. Pfeffer C, Larsen S, Song J, Dong M, Besenbacher F, Meyer RL, et al. Filamentous bacteria transport electrons over centimetre distances. Nature. 2012;491(7423):218-21. doi:10.1038/nature11586.

70. Sharma M, Aryal N, Sarma PM, Vanbroekhoven K, Lal B, Benetton $X D$, et al. Bioelectrocatalyzed reduction of acetic and butyric acids via direct electron transfer using a mixed culture of sulfate-reducers drives electrosynthesis of alcohols and acetone. Chem Commun. 2013;49(58):6495-7. doi:10.1039/C3CC42570C.

71. Beese-Vasbender PF, Nayak S, Erbe A, Stratmann M, Mayrhofer KJJ. Electrochemical characterization of direct electron uptake in electrical microbially influenced corrosion of iron by the lithoautotrophic SRB Desulfopila corrodens strain IS4. Electrochim Acta. 2015;167:321-9. doi:10.1016/j.electacta.2015.03.184.

72. Rodrigues TdC, Rosenbaum MA. Microbial electroreduction: screening for new cathodic biocatalysts. ChemElectroChem. 2014;1(11):1916-22. doi:10.1002/celc.201402239.

73. Nie H, Zhang T, Cui M, Lu H, Lovley DR, Russell TP. Improved cathode for high efficient microbial-catalyzed reduction in microbial electrosynthesis cells. Phys Chem Chem Phys. 2013;15(34):14290-4. doi:10.1039/ C3CP52697F.

74. Jourdin L, Freguia S, Donose BC, Chen J, Wallace GG, Keller J, et al. A novel carbon nanotube modified scaffold as an efficient biocathode material for improved microbial electrosynthesis. J Mater Chem A. 2014:2(32):13093-102. doi:10.1039/C4TA03101F.

75. Flexer V, Chen J, Donose BC, Sherrell P, Wallace GG, Keller J. The nanostructure of three-dimensional scaffolds enhances the current density of microbial bioelectrochemical systems. Energ Environ Sci. 2013;6(4):1291-8. doi:10.1039/C3EE00052D.

76. Yan H, Catania C, Bazan GC. Membrane-intercalating conjugated oligoelectrolytes: Impact on bioelectrochemical systems. Adv Mater. 2015:n/a-n/a. doi:10.1002/adma.201500487.

77. Jourdin L, Grieger T, Monetti J, Flexer V, Freguia S, Lu Y, et al. High acetic acid production rate obtained by microbial electrosynthesis from carbon dioxide. Environ Sci Technol. 2015. doi:10.1021/acs.est.5b03821.

78. Su M, Wei L, Qiu Z, Jia Q, Shen J. A graphene modified biocathode for enhancing hydrogen production. RSC Advances. 2015;5(41):32609-14. doi:10.1039/C5RA02695D.

79. Foley JM, Rozendal RA, Hertle CK, Lant PA, Rabaey K. Life cycle assessment of high-rate anaerobic treatment, microbial fuel cells, and microbial electrolysis cells. Environ Sci Technol. 2010;44(9):3629-37. doi:10.1021/es100125h.

80. Pant D, Singh A, Van Bogaert G, Gallego YA, Diels L, Vanbroekhoven K. An introduction to the life cycle assessment (LCA) of bioelectrochemical systems (BES) for sustainable energy and product generation: relevance and key aspects. Renew Sust Energ Rev. 2011;15(2):1305-13. doi:10.1016/j.rser.2010.10.005.

81. Steinbusch KJJ, Hamelers HVM, Schaap JD, Kampman C, Buisman CJN. Bioelectrochemical ethanol production through mediated acetate reduction by mixed cultures. Environ Sci Technol. 2010;44(1):513-7. doi:10.1021/es902371e.

82. Park DH, Zeikus JG. Utilization of electrically reduced neutral red by Actinobacillus succinogenes: physiological function of neutral red in membrane-driven fumarate reduction and energy conservation. J Bacteriol. 1999;181(8):2403-10.

83. Park DH, Laivenieks M, Guettler MV, Jain MK, Zeikus JG. Microbial utilization of electrically reduced neutral red as the sole electron donor for growth and metabolite production. Appl Environ Microbiol. 1999:65(7):2912-7. 
84. Emde R, Schink B. Enhanced propionate formation by Propionibacterium freudenreichii subsp. freudenreichii in a three-electrode amperometric culture system. Appl Environ Microbiol. 1990;56(9):2771-6.

85. Kracke F, Krömer JO. Identifying target processes for microbial electrosynthesis by elementary mode analysis. BMC Bioinform. 2014;15(1):410. doi:10.1186/s12859-014-0410-2.

86. Wang A-J, Cheng H-Y, Liang B, Ren N-Q, Cui D, Lin N, et al. Efficient reduction of nitrobenzene to aniline with a biocatalyzed cathode. Environ Sci Technol. 2011;45(23):10186-93. doi:10.1021/es202356w.

87. Dennis PG, Harnisch F, Yeoh YK, Tyson GW, Rabaey K. Dynamics of cathode-associated microbial communities and metabolite profiles in a glycerol-fed bioelectrochemical system. Appl Environ Microbiol. 2013;79(13):4008-14. doi:10.1128/aem.00569-13.

88. Schlager S, Neugebauer H, Haberbauer M, Hinterberger G, Sariciftci NS Direct electrochemical addressing of immobilized alcohol dehydrogenase for the heterogeneous bioelectrocatalytic reduction of butyraldehyde to butanol. ChemCatChem. 2015;7(6):967-71. doi:10.1002/ cctc.201402932.

89. Dellomonaco C, Clomburg JM, Miller EN, Gonzalez R. Engineered reversal of the $\beta$-oxidation cycle for the synthesis of fuels and chemicals. Nature. 2011;476(7360):355-9. doi:10.1038/nature10333.

90. Van Eerten-Jansen MCAA, Ter Heijne A, Grootscholten TIM, Steinbusch KJJ, Sleutels THJA, Hamelers HVM, et al. Bioelectrochemical production of caproate and caprylate from acetate by mixed cultures. ACS Sustain Chem Eng. 2013;1(5):513-8. doi:10.1021/sc300168z.

91. Lozecznik S, Sparling R, Clark SP, VanGulck JF, Oleszkiewicz JA. Acetate and propionate impact on the methanogenesis of landfill leachate and the reduction of clogging components. Biores Technol. 2012;104:37-43. doi:10.1016/j.biortech.2011.09.123.

92. Sharma M, Aryal N, Sarma PM, Vanbroekhoven K, Lal B, Benetton $X \mathrm{D}$, et al. Bioelectrocatalyzed reduction of acetic and butyric acids via direct electron transfer using a mixed culture of sulfate-reducers drives electrosynthesis of alcohols and acetone. Chem Commun. 2013;49(58):6495-7. doi:10.1039/C3CC42570C.

93. Zhou M, Chen J, Freguia S, Rabaey K, Keller J. Carbon and electron fluxes during the electricity driven 1,3-propanediol biosynthesis from glycerol. Environ Sci Technol. 2013;47(19):11199-205. doi:10.1021/ es402132r.

94. Srikanth S, Venkateswar Reddy M, Venkata Mohan S. Microaerophilic microenvironment at biocathode enhances electrogenesis with simultaneous synthesis of polyhydroxyalkanoates ( $\mathrm{PHA}$ ) in bioelectrochemical system (BES). Biores Technol. 2012;125:291-9. doi:10.1016/j. biortech.2012.08.060.

95. Hawkins AS, Han Y, Lian H, Loder AJ, Menon AL, Iwuchukwu IJ, et al. Extremely thermophilic routes to microbial electrofuels. ACS Catal. 2011;1(9):1043-50. doi:10.1021/cs2003017.

96. Conrado R, Haynes C, Haendler B, Toone E. Electrofuels: a new paradigm for renewable fuels. Advanced Biofuels and Bioproducts. New York: Springer; 2013.

97. Hawkins AS, McTernan PM, Lian H, Kelly RM, Adams MWW. Biological conversion of carbon dioxide and hydrogen into liquid fuels and industrial chemicals. Curr Opin Biotech. 2013;24(3):376-84. doi:10.1016/j. copbio.2013.02.017

98. Tremblay P-L, Zhang T. Electrifying microbes for the production of chemicals. Front Microbiol. 2015. doi:10.3389/fmicb.2015.00201.
99. Marshall CW, Ross DE, Fichot EB, Norman RS, May HD. Long-term operation of microbial electrosynthesis systems improves acetate production by autotrophic microbiomes. Environ Sci Technol. 2013;47(11):6023-9. doi:10.1021/es400341b.

100. Ganigue R, Puig S, Batlle-Vilanova P, Balaguer MD, Colprim J. Microbial electrosynthesis of butyrate from carbon dioxide. Chem Commun. 2015:51(15):3235-8. doi:10.1039/C4CC10121A.

101. Torella JP, Gagliardi CJ, Chen JS, Bediako DK, Colón B, Way JC, et al. Efficient solar-to-fuels production from a hybrid microbial-water-splitting catalyst system. Proc Natl Acad Sci. 2015;112(8):2337-42. doi:10.1073/ pnas.1424872112

102. Hsu L, Masuda SA, Nealson KH, Pirbazari M. Evaluation of microbial fuel cell Shewanella biocathodes for treatment of chromate contamination. RSC Adv. 2012;2(13):5844-55. doi:10.1039/C2RA20478A.

103. Rozendal RA, Jeremiasse AW, Hamelers HVM, Buisman CJN. Hydrogen production with a microbial biocathode. Environ Sci Technol. 2008;42(2):629-34. doi:10.1021/es071720+.

104. Jeremiasse AW, Hamelers HVM, Buisman CJN. Microbial electrolysis cell with a microbial biocathode. Bioelectrochemistry. 2010;78(1):39-43. doi:10.1016/j.bioelechem.2009.05.005.

105. Van Eerten-Jansen MCAA, Heijne AT, Buisman CJN, Hamelers HVM. Microbial electrolysis cells for production of methane from $\mathrm{CO}_{2}$ : longterm performance and perspectives. Int J Energy Res. 2012;36(6):80919. doi:10.1002/er.1954.

106. Nevin KP, Hensley SA, Franks AE, Summers ZM, Ou J, Woodard TL, et al. Electrosynthesis of organic compounds from carbon dioxide is catalyzed by a diversity of acetogenic microorganisms. Appl Environ Microb. 2011;77(9):2882-6. doi:10.1128/aem.02642-10.

107. Nevin KP, Woodard TL, Franks AE, Summers ZM, Lovley DR. Microbial electrosynthesis: Feeding microbes electricity to convert carbon dioxide and water to multicarbon extracellular organic compounds. mBio. 2010;1(2). doi:10.1128/mBio.00103-10.

108. Sato K, Kawaguchi H, Kobayashi H. Bio-electrochemical conversion of carbon dioxide to methane in geological storage reservoirs. Energy Convers Manag. 2013;66:343-50. doi:10.1016/j.enconman.2012.12.008.

109. Pitts KE, Dobbin PS, Reyes-Ramirez F, Thomson AJ, Richardson DJ, Seward HE. Characterization of the Shewanella oneidensis MR-1 decaheme cytochrome MtrA: expression in Escherichia coli confers the ability to reduce soluble Fe(III) chelates. J Biol Chem. 2003;278(30):27758-65. doi:10.1074/jbc.M302582200.

110. Gorby Y, McLean J, Korenevsky A, Rosso K, El-Naggar MY, Beveridge TJ. Redox-reactive membrane vesicles produced by Shewanella. Geobiology. 2008;6(3):232-41. doi:10.1111/j.1472-4669.2008.00158.x.

111. Hartshorne R, Jepson B, Clarke T, Field S, Fredrickson J, Zachara J, et al. Characterization of Shewanella oneidensis MtrC: a cell-surface decaheme cytochrome involved in respiratory electron transport to extracellular electron acceptors. JBIC, J Biol Inorg Chem. 2007;12(7):1083-94. doi:10.1007/s00775-007-0278-y.

\section{Submit your next manuscript to BioMed Central and we will help you at every step:}

- We accept pre-submission inquiries

- Our selector tool helps you to find the most relevant journal

- We provide round the clock customer support

- Convenient online submission

- Thorough peer review

- Inclusion in PubMed and all major indexing services

- Maximum visibility for your research

Submit your manuscript at www.biomedcentral.com/submit

() Biomed Central 